\title{
Tribute to Emmet Keeffe
}

\section{David Lieberman}

Published online: 3 March 2015

(C) Springer Science+Business Media New York 2015

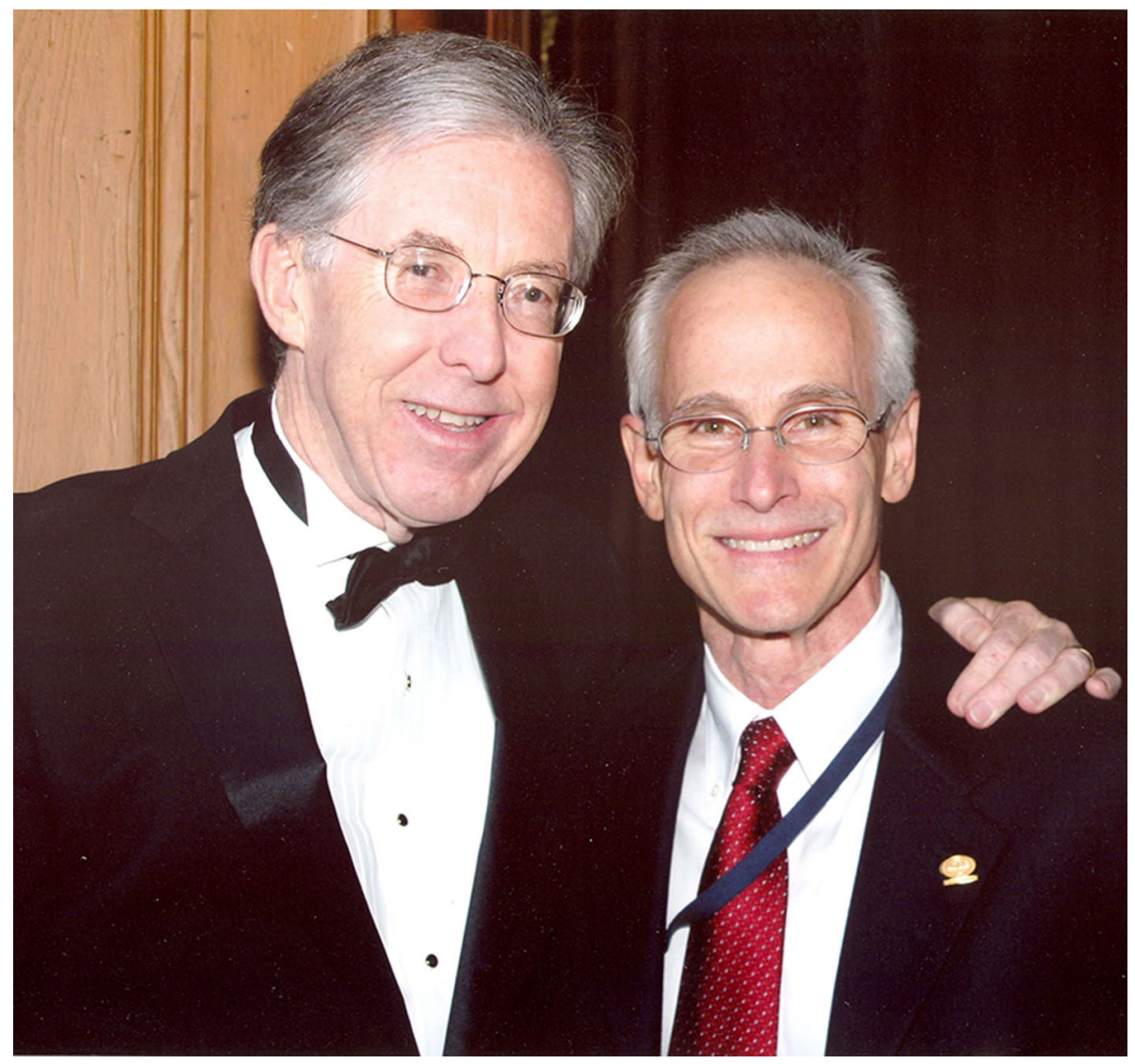

When Emmet Keeffe served as Editor of Digestive Diseases and Sciences (2008-2011), he worked tirelessly to make this journal relevant and vital to both clinicians and

\section{Lieberman $(\bowtie)$}

Division of Gastroenterology and Hepatology, Oregon Health and Science University, L 4613181 SW Sam Jackson Park Rd, Portland, OR 97239, USA

e-mail: lieberma@ohsu.edu basic scientists. When he passed away suddenly, in August, 2011, the journal lost an inspirational leader, but retained his vision. This issue is a tribute to his legacy and I am honored to add some words of tribute to this remarkable man, I was privileged to call my friend.

Emmet grew up in the San Francisco Bay Area and attended the University of San Francisco. He received his MD from Creighton University and came to Oregon Health Sciences University for internship, medical residency, and 
GI fellowship. After fulfilling his military obligation at the Oakland Naval Regional Medical Center, he returned to UCSF for research training in hepatology with Bruce Scharschmidt and Robert Ockner. He acquired all of the tools of a strong investigator, a spirit of inquiry and critical thinking skills, and he became an erudite writer and communicator. He returned to Oregon in 1979 to join the faculty, and I was fortunate to meet Emmet during my GI fellowship, when he became my mentor and close friend.

Emmet remained a "man for all seasons" throughout his career, although he would ultimately focus on hepatology as his primary clinical and research niche. His publications include subjects in almost every sphere of gastroenterology and hepatology, including colorectal cancer. During his Oregon years (1979-1992), he became the Medical Director of a new Liver Transplant program in 1988. In 1992, he returned to his roots in San Francisco to become the Medical Director of Liver Transplant at California Pacific Medical Center and in 1995 moved on to Stanford in a similar role. His career spanned a remarkable era in hepatology, and he was in the thick of it with research contributions in viral hepatitis, hepatocellular carcinoma, and liver transplantation.

Among his many wonderful qualities, Emmet was a consummate communicator-both as a writer and lecturer. He had a remarkable ability to distill complex concepts and develop clear, balanced, and practical clinical guidance. His crisp, precise writing served him well in his many editorial capacities and ultimately as Editor of Digestive Diseases and Sciences. During my early career, I was fortunate to work with him on several research projects and manuscripts, and observe his editorial skills personally. He was a craftsman, and wordsmith, who provided just the right balance of constructive criticism and support to make me a better writer. Being a writer (700 plus publications) and Editor was just part of his DNA, and he loved it.

He was a gifted teacher. He measured his success as an educator by the success of his students and generously gave credit to others. He set the bar high, expecting rigor and hard work, which was nothing less than he expected from himself. As a physician, he was beloved by his patients. He was warm and compassionate, and was recognized nationally for his clinical wisdom. He was also a remarkable leader-one of the few individuals to serve as president of two large GI organizations: ASGE and AGA, as well as many other leadership positions. This does not happen by accident. Leadership roles settled upon Emmet because he was recognized as a fair and honest broker who could bridge gaps, build consensus, and earn respect. There was no ego involved, and I think one of the secrets of his success as a leader was his humility and willingness to give credit to others.

What really endeared Emmet to everyone who knew him was his warmth, respect for others, and humor. During our long runs and back-packing adventures, we talked about many things, but none more important than family. During his life, his family kept him grounded. His wife, Melenie, and children Emmet III, Brian, Meghan, their spouses, and his grandchildren were his greatest source of joy. They were his anchor.

Emmet Keeffe was a remarkable human being whose legacy is a loving family, indebted students, and friends throughout the world. His work as a teacher, writer, and Editor taught us the value of critical thinking. He would be especially pleased with this special issue on Colorectal Cancer Screening and proud of the esteemed group of authors who have contributed. 